\section{八戸漁港における金属紫および紙製魚箱の用} 途

\section{四津隆一}

さきに著者は八戸・気仙沼・石巻・塩釜の 4 漁港の調査により，三陸主要漁港の製函業につ いて報告し，原木の不足と木箱代用材料の 改良から, 鮮魚容器の転換を予想したが, とく に木製魚箱生産に焦点をあてて論述した（四津 1967）以後の地理学研究では著者の管見による と、魚箱生産に関する報告は見あたらない。従 ってすでに発表した報告を補足する目的で，木 製魚箱以外の魚箱について検討することとす る。水揚量 31 万トン. 漁獾額 120 億円 (1967 年) におよぶ八戸漁港では八戸漁港製函株式会社， 八戸近海漁業協同組合，八戸市白銀漁業協同組 合以外，一応製函業者は八戸港製函事業協同組 合，八戸漁港鲛製函 事業協同組合，八戸中央 慗函協同組合の 3 組合に統合され，他の漁港の 製函業者よりも多数集中するとともに、はるか にまとまっている。1963 年設立され，1967年 鲛か门湊町へ移転した株式会社八戸水産公社 か，魚箱代金を漁業者から集めるなどの雑務を 代行することにより，製函業者の企業の安全を 図り，さらに 10〜11 月の八戸港でイカ・サバ の水揚が集中・競合して木製魚箱が需要量にお よばなくなる場合を考虑して，鮮魚用金属製魚 箱を 15 万箱準備している。製造地は東京 (日本 魚函サービス株式会社) で，木製魚箱が漁港付近 で生産されているのとは対照的である。1962年 に金属製魚箱が使用され始めると同時に延 55
万箱の使用といら普及ぶりをその年に示した が，以後不評を買い年間 16,000 箱の使用にま で転落した (1964年)。1965 年以降鮮魚金属魚箱 は, 北洋サケ・マス漁業に出漁した 84 隻の大 部分に積み込まれた注か，サバの地元保管用を 中心に延 30 万箱（1967年）が使われるよ5にな り，一応流行的普及の段階を脱して，金属慗魚 箱の利点の再認識に基いて着実に利用されよ としている。一方他の木製魚箱の代用品として 鮮魚用耐水ダンボール魚箱があげられる。これ は1966 年試験的に使用され始め, 1967 年には サパの県外向けに 12,000 箱使われた。耐水ダ ンボール魚箱は金属製または木製魚箱の大部分 とは異って, 使用が一回限りである点で県外の よ5な遠距離輸送に使用されているのである。

以上のよ5に鮮魚の容器として木製魚箱を 使用していたが，魚の種類により木彆魚箱の不 足の時期に，木製魚箱代用の金属製ないし耐水 ダンボール魚箱が使用されている。そしてめる 程度それらの利用が軌道に乗りはじめたように 考えられる。しかし鮮魚容器における木製魚箱 の地位は他の追随を許さず，ここにあげた代用 魚箱は木製魚箱にくらべれば九牛の一毛にすぎ ない。木製魚箱に関して近年宣伝される木材資 源の払底に基ずく原料難と代用魚箱の質的向上 ・コスト面の改善による普及が，影響をあたえ ているよらに予想されたが，現在はその萠芽を 指摘できるにすぎない。(1968.7. 27 受理)

四津隆一（196i）：三陸における主要漁港の製函業 東北地理 $19 \quad 89 \sim 93$

\title{
The Use of Metal and Cardboard Fish-cases in Hachinohe Ryuichi YoTsU
}

In 1967, the author published an article on the wooden fish-cases in big fishing ports along the Sanriku coast. This is a report of the author's investigation on the use of metal and cardboard fish-cases in Hachinohe. The metal and cardboard cases are used to meet the shortage of the wooden cases in the season of large quantity of landing during the period from October to November. Such cases have been in use especially for mackerel since 1962. 